\title{
Chondrosarcoma of the Cavernous Sinus
} Kavernöz Sinüs Kondrosarkomu

Keywords: Chondrosarcoma, cavernous sinus, CT, MRI

Anahtar Kelimeler: Kondrosarkom, kavernöz sinüs, BT, MRG

\section{Dear Editor,}

A 40-year-old female patient was admitted to our department with symptoms of headache, ophthalmoplegia, and numbness. The patient was investigated using cranial computed tomography (CT) and contrast-enhanced cerebral magnetic resonance imaging with suspicion of a skull base mass. Unenhanced cranial CT showed a heterogeneous calcified mass arising from the right cavernous sinus and expanding into the prepontine cistern, sellar-suprasellar cistern, cerebellopontine angle, sphenoid sinus, superior orbital fissure, and optic canal. Also, the mass depressed the right side of the pons, the cavernous segment of the carotid artery, and elevated the supraclinoid segment of the carotid artery. The mass was heterogeneous hypointense on unenhanced T1WI, heterogeneous hyperintense on T2WI and fluid-attenuated inversion recovery, it had heterogeneous blooming calcified proportions on gradient echo- susceptibility weighted imaging, and heterogeneous intense contrast enhancement after contrast administration (Figure 1). Complete tumor resection via the infratemporal approach was performed and histopathology was reported as low-grade chondrosarcoma.

Cranial chondrosarcomas are generally slow growing and rarely malignant, and usually arise at the synchondrosis of the skull base, particularly the sphenopetroclival synchondrosis $(1,2)$. Chordomas and chondrosarcomas are similar in anatomic location, clinical presentation, and radiologic findings, but quite different in clinicopathologic findings and outcomes (2). Chondrosarcomas can locally invade the cavernous sinus (CS). The $\mathrm{CS}$ is a complex and loculated venous space that contains crucial neurovascular structures including the venous plexus, internal carotid artery, periarterial sympathetic nerves, cranial nerves $(\mathrm{CN}$ III, IV, $\mathrm{V}_{1}, \mathrm{~V}_{2}, \mathrm{VI}$,) and fibrous tissue. When the CS is infiltrated by tumor, CS syndrome may develop, which is characterized by ophthalmoplegia, chemosis, proptosis, and Horner's syndrome $(1,3)$. On CT, a heterogeneous calcified soft-tissue mass is often seen within the synchondrosis and lateral to midline chordomas. Typically, the lesion is heterogeneous iso-hypointense on T1 and hyperintense on $\mathrm{T} 2$, diffusion restriction and frequently enhanced with gadolinium $(1,2,4)$. Surgical resection has been the mainstay of treatment for intracranial chondrosarcomas, combined with adjuvant radiotherapy and chemotherapy to improve recurrence rates and overall survival (5). Imaging techniques are useful in diagnosis of skull base tumors. Knowledge of its radiologic findings allows accurate diagnosis and also has a direct impact on clinical and surgical management.

\footnotetext{
Address for Correspondence/Yazışma Adresi: Esin Kurtuluş Öztürk MD, Kutahya University of Health Sciences Faculty of Medicine, Department of Radiology, Kutahya, Turkey

Phone: +90 5059483683 E-mail: e.kurtulus@ hotmail.com ORCID: orcid.org/0000-0001-6046-3486

Received/Geliş Tarihi: 06.09.2019 Accepted/Kabul Tarihi: 11.11.2019

${ }^{\oplus}$ Copyright 2020 by Turkish Neurological Society

Turkish Journal of Neurology published by Galenos Publishing House.
} 

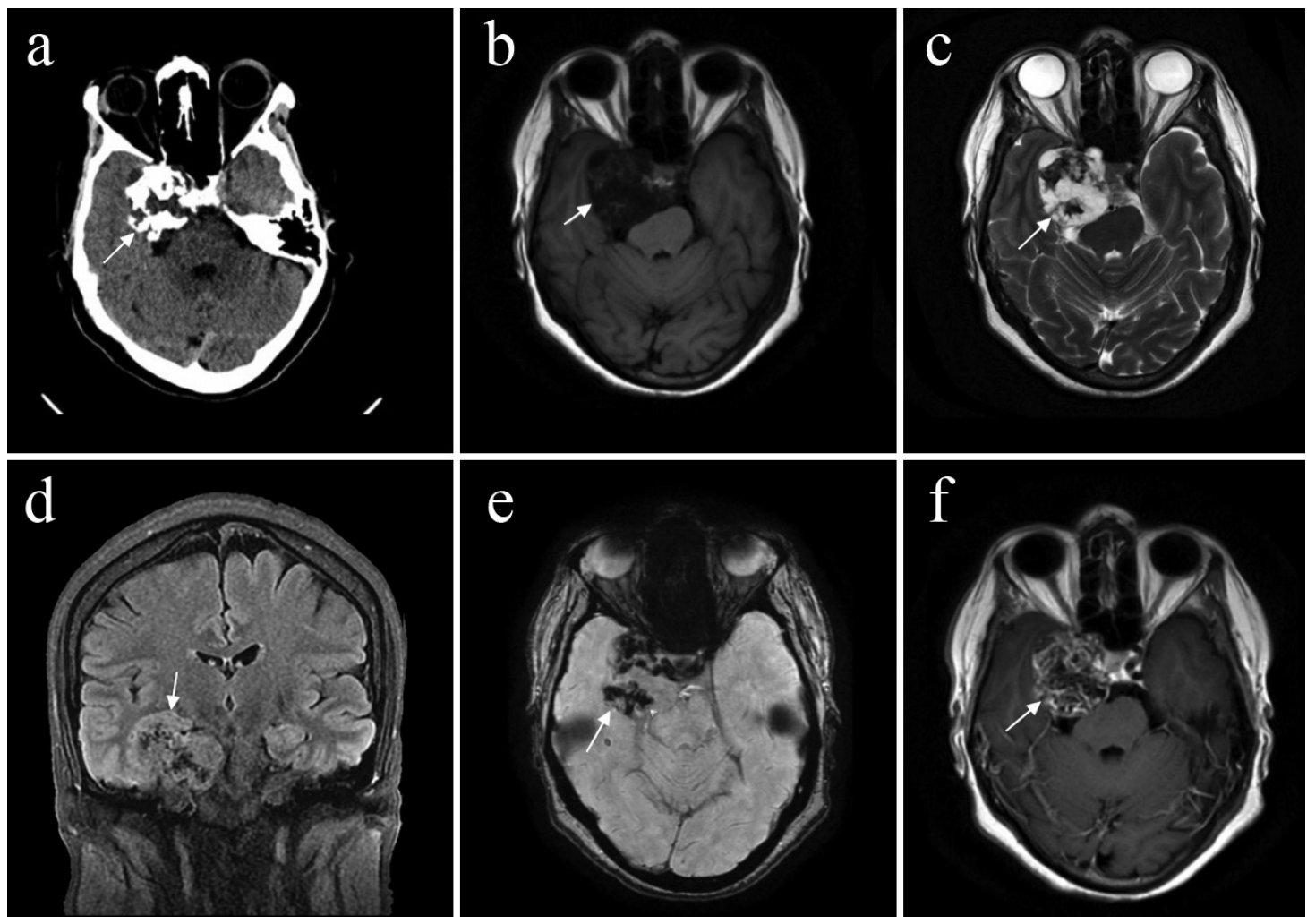

Figure 1. An axial unenhanced brain CT image (a) shows a heterogenous calcified mass (arrow) arising from the right cavernous sinus and expanding into prepontin cistern, sellar-suprasellar cistern, cerebellopontin angle, sphenoid sinus, superior orbital fissure and optic canal. The mass (arrow) is heterogenous hypointense on axial unenhanced T1 image (b), heterogenous hyperintense on axial T2 image (c) and coronal FLAIR image (d), blooming calcified proportions (arrowhead) on axial gradient echo-SWI image (e) and heterogenous intense on axial contrast-enhanced T1 image (f)

CT: Computed tomography, FLAIR: Fluid-attenuated inversion recovery, SWI: Susceptibility weighted imaging

\section{Ethics}

Informed Consent: Formal consent is not required for this type of study.

Peer-review: Externally peer-reviewed.

\section{Authorship Contributions}

Surgical and Medical Practices: S.S., Concept: E.K.Ö., Design: S.S., Data Collection or Processing: S.Ö., Analysis or Interpretation: E.K.Ö., Literature Search: E.K.Ö., S.Ö., Writing: E.K.Ö.

Conflict of Interest: No conflict of interest was declared by the authors.

Financial Disclosure: The authors declared that this study received no financial support.

\section{References}

1. Razek AA, Castillo M. Imaging lesions of the cavernous sinus. AJNR Am J Neuroradiol 2009;30:444-452.

2. Almefty K, Pravdenkova S, Colli BO, Al-Mefty O, Gokden M. Chordoma and chondrosarcoma: similar, but quite different, skull base tumors. Cancer 2007; 110:2457-2467.

3. Tang Y, Booth T, Steward M, Solbach T, Wilhelm T. The imaging of conditions affecting the cavernous sinus. Clin Radiol 2010;65:937-945.

4. Van Gompel JJ, Janus JR. Chordoma and chondrosarcoma. Otolaryngol Clin North Am 2015;48:501-514.

5. Wanebo JE, Bristol RE, Porter RR, Coons SW, Spetzler RF. Management of cranial base chondrosarcomas. Neurosurgery 2006;58:249-255. 